\title{
Flow injection-differential pulse anodic stripping voltammetry to measure As(III) and As(V) in natural water samples
}

\author{
Supunnee Duangthong ${ }^{\mathrm{a}, *}$, Amornrat Suwanin ${ }^{\mathrm{b}}$, Pipat Chooto ${ }^{\mathrm{a}}$, Chalermpol Innuphat ${ }^{\mathrm{a}}$ \\ a Department of Chemistry, Analytical Chemistry Division, Faculty of Science, \\ Prince of Songkla University, Hatyai, Songkhla 90112 Thailand \\ b Lamae Wittaya School, Lamae Sub District, Lamae, Chumphon 86170 Thailand
}

*Corresponding author, e-mail: supunnee.d@psu.ac.th

ABSTRACT: Flow injection-differential pulse anodic stripping voltammetry (FI-DPASV) for As(III) and As(V) determination at parts-per-billion (ppb) level was developed with gold film coated glassy carbon as a working electrode. As(III) was determined first by FI-DPASV. Then, As(total) was determined by reducing As(V) to As(III) using $6.5 \mathrm{mM}$ $\mathrm{KI}$ for $45 \mathrm{~min}$, and $\mathrm{As}(\mathrm{V})$ was quantified as the difference. Parameters for the pre-plated gold film electrode in As(III) and $\mathrm{As}(\mathrm{V})$ determination were optimized to obtain linear calibration graphs in the range of 1.0-30 $\mu \mathrm{g} / 1$ and 2.0$100 \mu \mathrm{g} / 1$ for As(III) and As(total), respectively. The limits of detection (based on $3 S_{y / x} / \mathrm{m}$ ) of $0.81 \mu \mathrm{g} / 1 \mathrm{As}$ (III) and $2.03 \mu \mathrm{g} / 1$ As(total) were obtained with a precision within 4\% (at 2 and $20 \mu \mathrm{g} / 1, n=10$ ) for As(III) and within 6\% (at 10 and $100 \mu \mathrm{g} / 1, n=10$ ) for As(total). Analysis of the Standard Reference Material 1640 natural water standard with the certified value of $26.67 \pm 0.41 \mu \mathrm{g} / 1$ yielded total arsenic concentration of $25.2 \pm 0.7 \mu \mathrm{g} / \mathrm{l}(n=3)$. For cations commonly found in natural water, $\mathrm{Sb}$ (III) was found to interfere with As(III) analysis whereas $\mathrm{Hg}$ (II) and Cu(II) interfere with As(total) determination. The developed method was successfully applied to natural water samples collected from arsenic contaminated areas in Ron Phibun Subdistrict, Ron Phibun District, Nakhon Si Thammarat Province in Thailand. The recoveries of the method by spiking were in the range of $85-105 \%$. The results of As(total) in natural water samples analysed by the developed method (FI-DPASV) were in good agreement with those obtained by inductively coupled plasma-optical emission spectrometry.

KEYWORDS: gold film electrode, arsenic speciation

\section{INTRODUCTION}

Arsenic, a toxic and carcinogenic element, has profound effects on plants, animals, and human health. It is a naturally occurring element present in the environment in both inorganic and organic forms. Inorganic arsenic is considered to be the most toxic form with major oxidation states in natural water of As(III) and As(V). Since As(III) is more toxic than $\mathrm{As}(\mathrm{V})$, speciation analysis of arsenic species is very important compared to total arsenic determination.

There are several analytical method for arsenic speciation including hydride generation atomic absorption spectrometry ${ }^{1}$, hydride generation atomic fluorescence spectrometry ${ }^{2}$, graphite furnace atomic absorption spectrometry ${ }^{3}$, and inductively coupled plasma mass spectrometry ${ }^{4}$. Despite satisfactory detection limits, these techniques require expensive instruments and high running cost.
Electrochemical techniques including polarography $^{5}$, cyclic voltammetry ${ }^{6}$, potentiometry ${ }^{7}$ cathodic stripping voltammetry, and anodic stripping voltammetry (ASV) ${ }^{8}$ can differentiate the oxidation states of arsenic with great sensitivity. These techniques provide low-cost, rapid and portable options for in-field routines ${ }^{9}$. Specifically, stripping analysis is advantageous for trace determination in real samples because the substance of interest can be preconcentrated on the working electrode.

Forsberg et $\mathrm{al}^{10}$ investigated in detail the determination of arsenic by ASV and differential pulse anodic stripping voltammetry (DPASV) at various working electrodes such as HMDE, Pt, and Au. It was found that the arsenic oxidation peak appeared as a shoulder on the mercury oxidation wave on an HMDE. Gold solid electrode was found to be better than platinum as a working electrode material due to a higher hydrogen overvoltage and better reversibility ${ }^{11}$ of the electrode reaction in the plat- 
ing and stripping steps. However, solid electrodes have the problems of memory effect which varies with pretreatment and formation of oxide films and results in limited sensitivity and reproducibility of the determination. To overcome this problem, a renewable gold film electrode ${ }^{11,12}$ which minimizes contamination from previous analysis is utilized. Factors affecting the performance of the electrode including plating potential, plating time, concentration of $\mathrm{Au}(\mathrm{III})$ solution, and flow rate of $\mathrm{Au}(\mathrm{III})$ were optimized.

The total inorganic arsenic content analysis is normally based on converting all arsenic species to the trivalent arsenic form which is then determined by electrochemical techniques. Pentavalent arsenic is electroinactive ${ }^{13,14}$. Hence the requirement of the reduction to As(III). Reducing agents including sodium thiosulphate $\left(\mathrm{Na}_{2} \mathrm{~S}_{2} \mathrm{O}_{3}\right)$, sodium dithionite $\left(\mathrm{Na}_{2} \mathrm{~S}_{2} \mathrm{O}_{4}\right)$, L-cysteine, KI as well as a mixture of ascorbic acid and KI were investigated here.

As batch analysis is slow, requires a large volume of the sample and reagent consumption, is susceptible to contamination, and has poor reproducibility, flow injection system was applied here in combination with differential pulse anodic stripping voltammetry to analyse water samples from arsenic contaminated areas in Ron Phibun Subdistrict, Ron Phibun District, Nakhon Si Thammarat Province, Thailand ${ }^{15}$.

\section{MATERIALS AND METHODS}

\section{Chemicals}

All chemicals used throughout the analysis were of the highest purity as commercially available. As(III) stock solution $(1000 \mathrm{mg} / \mathrm{l})$ was prepared by dissolving $0.1320 \mathrm{~g}$ of $\mathrm{As}_{2} \mathrm{O}_{3}$ (Fluka) in the minimum amount of $5.0 \mathrm{M} \mathrm{NaOH}$. The resulting solution was adjusted to the $\mathrm{pH}$ of about 3.5 with $0.1 \mathrm{M} \mathrm{HCl}$ and then diluted to $100 \mathrm{ml}$ with deionized water. A $0.5 \mathrm{ml}$ of $1000 \mathrm{mg} / \mathrm{l}$ hydrazinium chloride was added to prevent oxidation of As(III) to $\mathrm{As}(\mathrm{V})$. As(V) stock solution $(1000 \mathrm{mg} / \mathrm{l})$ was prepared by dissolving $0.4162 \mathrm{~g}$ of $\mathrm{Na}_{2} \mathrm{HAsO}_{4} \cdot 7 \mathrm{H}_{2} \mathrm{O}$ (Fluka) in $100 \mathrm{ml}$ of de-ionized water ${ }^{16} . \mathrm{As}_{2} \mathrm{O}_{3}$ and $\mathrm{Na}_{2} \mathrm{HAsO}_{4} \cdot 7 \mathrm{H}_{2} \mathrm{O}$ salt were dried at $100^{\circ} \mathrm{C}$ for $2 \mathrm{~h}$ and placed in desiccator until constant weight before weighing. The As(III) and As(V) stock solutions were stored at $4^{\circ} \mathrm{C}$ and were kept to stability for at least 1 month $^{11}$. As(III) and As(V) working standard solutions were daily prepared by appropriate dilutions of the stock solution with $0.2 \mathrm{M} \mathrm{HCl}$. $\mathrm{Au}$ (III) solution $(100 \mathrm{mg} / \mathrm{l})$ was prepared by dissolving $0.0960 \mathrm{~g}$ of $\mathrm{KAuCl}_{4}$ (Fluka) and making up to $500 \mathrm{ml}$ with $1 \mathrm{M} \mathrm{H}_{2} \mathrm{SO}_{4}{ }^{11}$. Nitrogen gas (99.999\%) was used for purging oxygen in a solution to provide an inert atmosphere inside the flow cell.

\section{Apparatus}

The Autolab model PGSTAT 100 (Metrohm, Switzerland) combined with the GPES software was used with electrochemical flow cell model CC-5E (Bioanalytical system, USA) consisting of a glassy carbon electrode ( $2 \mathrm{~mm}$ diameter) as a support working electrode, an $\mathrm{Ag} / \mathrm{AgCl}$ electrode as a reference electrode and a stainless steel block as an auxiliary electrode. The sample or the standard solution was aspirated into the system by a peristaltic pump (Ismatec, Switzerland). The set up of flow injection differential pulse anodic stripping voltammetry (FIDPASV) system for As(III) and As(V) determination is depicted in Fig. 1.

\section{Preparation of gold film electrode}

The procedure of pre-plated gold film electrode was adapted from that by Sun et $\mathrm{al}^{11}$. A glassy carbon electrode and a stainless steel block were polished with alumina and rinsed with de-ionized water. To plate gold film, $\mathrm{Au}$ (III) solution was aspirated into the system with the experimenting flow rate and applied potential. The Au(III) solution was deposited

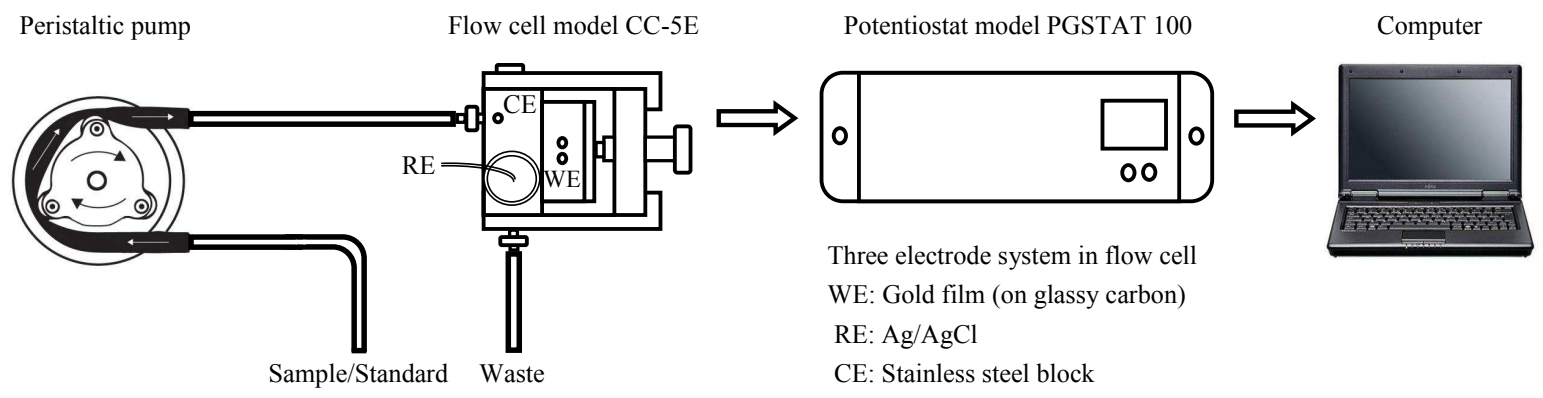

Fig. 1 The set up of flow injection-differential pulse anodic stripping voltammetry (FI-DPASV). 
on the glassy carbon electrode as a brown layer. To obtain a good gold film, parameters including plating potential, plating time, concentration of $\mathrm{Au}$ (III), and flow rate were optimized.

\section{As(III) determination}

After the gold film electrode was prepared, the As(III) determination step was carried out with pure nitrogen gas deaeration all the time during the analysis. An optimum deposition potential was applied to the electrode while As(III) solution was aspirated into the system. After deposition, the pump was switched off and $10 \mathrm{~s}$ of equilibration time was allowed. Finally, the stripping process was performed in the differential pulse mode starting from $-0.30 \mathrm{~V}$ to $0.50 \mathrm{~V}$. To obtain a good sensitivity, various parameters such as concentration of supporting electrolyte, deposition potential, deposition time, scan rate, and flow rate were optimized.

\section{As(V) determination}

After $\mathrm{As}(\mathrm{V})$ was off-line reduced to As(III) with optimum conditions, As(total) in the form of As(III) was analysed with the aforementioned procedure for As(III) determination. As(V) can be calculated from the difference of As(total) and As(III).

\section{Conversion of As(V) to As(III)}

A number of reducing agents including KI, a mixture of ascorbic acid and KI, sodium thiosulphate, sodium dithionite, and L-cysteine were investigated in terms of three parameters, namely type and concentration of the reducing agent and reduction time to achieve the best conversion.

\section{Interferences}

Various concentrations of the cation metals including $\mathrm{Sb}(\mathrm{III}), \mathrm{Cd}(\mathrm{II}), \mathrm{Cu}(\mathrm{II}), \mathrm{Fe}(\mathrm{II}), \mathrm{Pb}(\mathrm{II}), \mathrm{Hg}(\mathrm{II})$, $\mathrm{Ni}(\mathrm{II})$, and $\mathrm{Zn}$ (II) were added to $30 \mu \mathrm{g} / \mathrm{l}$ of As(III) and $30 \mu \mathrm{g} / \mathrm{l}$ of As(total) and then investigated with duplicate determinations. The interfering level was defined as the minimum concentration of interfering ion which produced $\%$ relative error exceeding $\pm 5 \%$.

\section{Sampling}

Natural water samples were collected from different areas in Ron Phibun Subdistrict, Ron Phibun District, Nakhon Si Thammarat Province, Thailand. The sampling points were restricted to the high risk arsenic contaminated regions ${ }^{17}$. A polyethylene bottle to store the sample was washed, soaked in

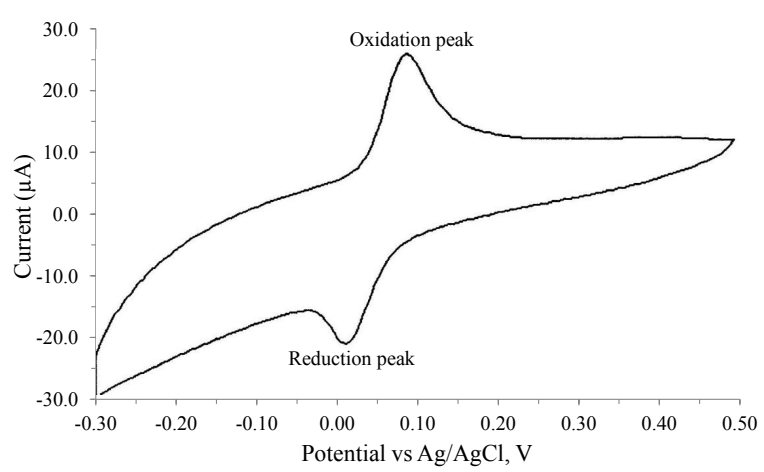

Fig. 2 The cyclic vtammogram of $10 \mathrm{mg} / 1 \mathrm{As}(\mathrm{III})$ standard solution in $0.2 \mathrm{M} \mathrm{HCl}$ at pre-plated gold film electrode with the scan rate of $50 \mathrm{mV} / \mathrm{s}$.

$10 \% \mathrm{HNO}_{3}$ for at least $24 \mathrm{~h}$, and then rinsed with deionized water. The sample was acidified by adding $0.5 \mathrm{ml}$ of concentrated $\mathrm{HNO}_{3}$ into $500 \mathrm{ml}$ water sample $(\mathrm{pH}<2)$ and kept into a cold box at $4{ }^{\circ} \mathrm{C}$ during transportation.

\section{RESULTS AND DISCUSSION}

\section{Cyclic voltammogram of As(III) at pre-plated gold film electrode}

Cyclic voltammetry was employed for preliminary study of electrochemical reaction of As(III) in $0.2 \mathrm{M}$ $\mathrm{HCl}$ as a supporting electrolyte. The potential window of gold film working electrode versus $\mathrm{Ag} / \mathrm{AgCl}$ was in the range of $-0.30-0.50 \mathrm{~V}$ at a scan rate of $50 \mathrm{mV} / \mathrm{s}$. The cyclic voltammogram of $10 \mathrm{mg} / 1$ As(III) in $0.2 \mathrm{M} \mathrm{HCl}$ revealed the peak potentials of $0.017 \mathrm{~V}$ and $0.091 \mathrm{~V}$, corresponding to the threeelectron reduction of As(III) to As(0) and oxidation of As(0) to As(III), respectively (Fig. 2). The welldefined oxidation peak confirms the capability of using the gold film electrode for As(III) determination by anodic stripping voltammetry.

\section{Optimization of pre-plated gold film electrodes}

$\mathrm{Au}(\mathrm{III})$ solution in $1.0 \mathrm{M} \mathrm{H}_{2} \mathrm{SO}_{4}$ was used as a plating solution ${ }^{11}$. Before plating, the working electrode and auxiliary electrode were polished with alumina. The conditions for pre-plated gold film electrode, i.e., plating potential, plating time, concentration of $\mathrm{Au}$ (III) solution and flow rate of $\mathrm{Au}(\mathrm{III})$ were optimized (Fig. 3). The plating potential which was applied to gold film electrode had a significant effect on the As(III) determination. With higher negative potential, higher current signal was obtained. The peak current slightly increased with the increase of plating potential and then continu- 

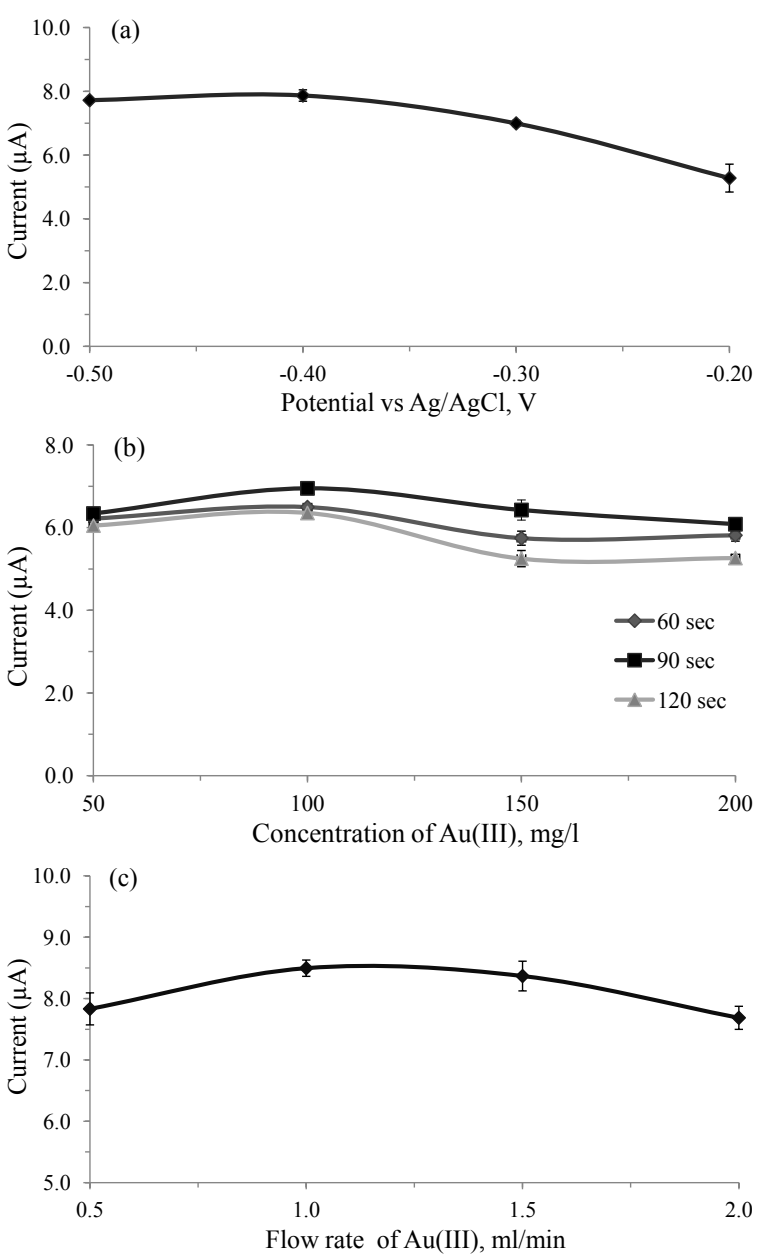

Fig. 3 (a) Effect of plating potential on $20 \mu \mathrm{g} / 1 \mathrm{As}$ (III) determination; (b) effect of plating time and concentration of $\mathrm{Au}$ (III) on $20 \mu \mathrm{g} / 1 \mathrm{As}$ (III) determination; (c) influence of the flow rate of $\mathrm{Au}$ (III) solution for pre-plated gold film electrode on $20 \mu \mathrm{g} / \mathrm{l}$ As(III) determination; deposition potential, $-0.30 \mathrm{~V}$; deposition time, $180 \mathrm{~s}$; scan rate, $100 \mathrm{mV} / \mathrm{s}$.

ously decreased at potentials greater than $-0.40 \mathrm{~V}$. The plating potential of $-0.40 \mathrm{~V}$, with the highest signal and reasonable precision, was selected for further studies. Optimization of Au(III) concentration of $100 \mathrm{mg} / \mathrm{l}$, plating time of $90 \mathrm{~s}$ and the flow rate of $1.0 \mathrm{ml} / \mathrm{min}$ were chosen as they provide the greatest sensitivity.

\section{Optimization of As(III) determination}

$\mathrm{HCl}$ is the most suitable supporting electrolytes for As(III) determination by anodic stripping voltammetry ${ }^{11}$, giving the highest sensitivity and narrowest peaks. Hence it was chosen as a supporting

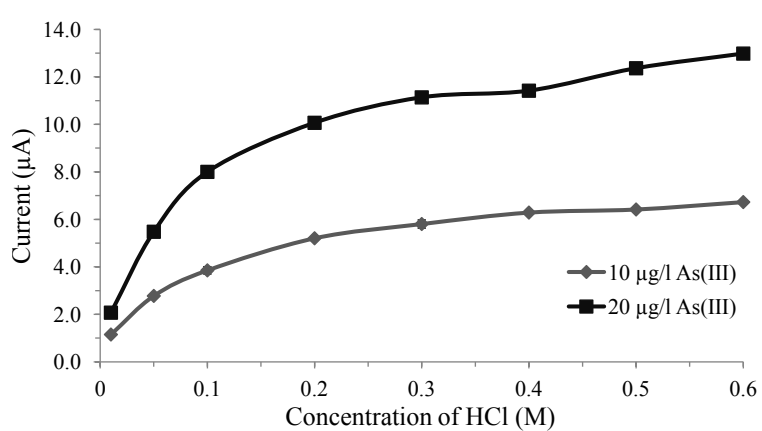

Fig. 4 Effect of $\mathrm{HCl}$ concentration as supporting electrolyte on 10 and $20 \mu \mathrm{g} / \mathrm{l}$ As(III) determination; deposition potential, $-0.30 \mathrm{~V}$; deposition time, $180 \mathrm{~s}$; scan rate, $100 \mathrm{mV} / \mathrm{s}$.

electrolyte. The concentrations of $\mathrm{HCl}$ were varied in the range of $0.01-0.60 \mathrm{M}$ for 10 and $20 \mu \mathrm{g} / 1$ As(III) (Fig. 4). It was remarkable that for both As(III) concentrations, the signal was higher with increasing $\mathrm{HCl}$ concentration. In conditions in which the $\mathrm{Cl}^{-}$concentration is high, however, the stability of gold film electrode is reduced due to the $\mathrm{AuCl}_{4}{ }^{-}$ formation ${ }^{11}$. To compromise between sensitivity and stability of the gold film electrode, $0.2 \mathrm{M} \mathrm{HCl}$ was selected for the subsequent experiments.

\section{Deposition potential}

Deposition potential is an important factor affecting sensitivity of As(III) determination. The optimization was examined by varying the deposition potential from -0.10 to $-0.40 \mathrm{~V}$ versus $\mathrm{Ag} / \mathrm{AgCl}$ with fixed deposition time of $180 \mathrm{~s}$ and scan rate of $100 \mathrm{mV} / \mathrm{s}$. The sensitivity of As(III) was evaluated from a slope of calibration curve for As(III) determination from the concentrations of $5,10,15$, and $20 \mu \mathrm{g} / \mathrm{l}$ As(III) standard solutions and was found to increase slightly, possibly due to the formation of $\mathrm{H}_{2}$ bubbles ${ }^{11}$, at more negative potential to reach a maximum at $-0.30 \mathrm{~V}$ and then decrease (Fig. 5). The deposition potential of $-0.30 \mathrm{~V}$ was therefore chosen due to the highest sensitivity and bubble avoidance.

\section{Flow rate of As(III)}

The effect of flow rate on As(III) determination was investigated by considering the slopes of calibration curve at different flow rates (data not shown). The sensitivity increased with increasing flow rate. A flow rate of $2.5 \mathrm{ml} / \mathrm{min}$ giving the maximum sensitivity was selected as an optimum flow rate. At flow rates higher than $2.5 \mathrm{ml} / \mathrm{min}$, the experiment could 


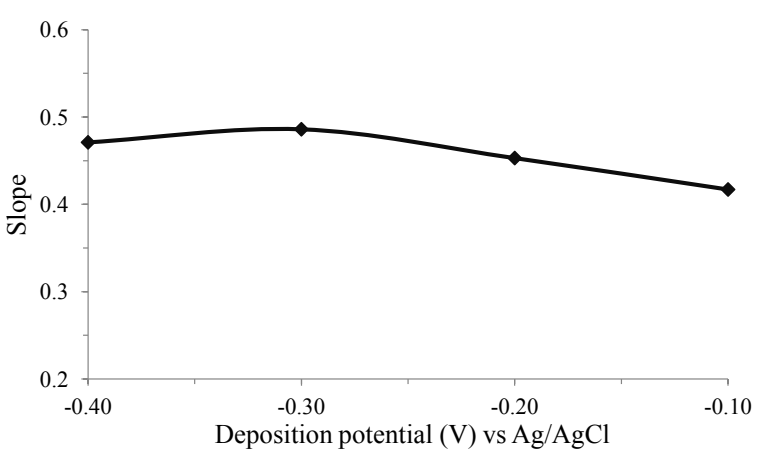

Fig. 5 Effect of the deposition potential on 5-20 $\mu \mathrm{g} / 1$ As(III) determination; deposition time, $180 \mathrm{~s}$; scan rate, $100 \mathrm{mV} / \mathrm{s}$.

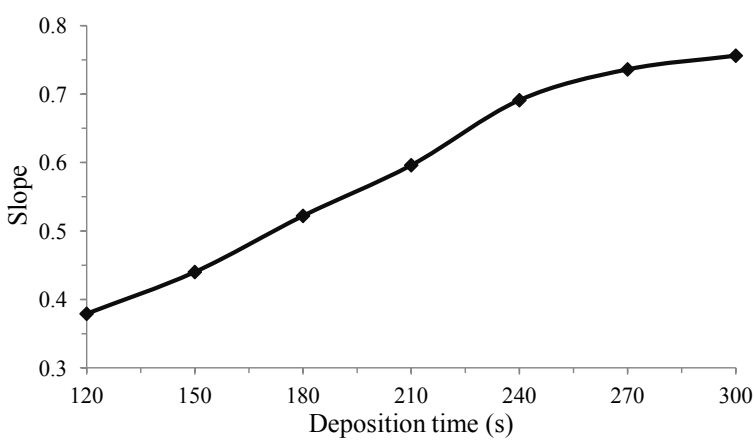

Fig. 6 Effect of the deposition time on 5-20 $\mu \mathrm{g} / 1$ As(III) determination; deposition potential, $-0.30 \mathrm{~V}$; scan rate, $90 \mathrm{mV} / \mathrm{s}$.

not be performed due to leakage. Additionally, deterioration of the gold film electrode may result.

\section{Scan rate}

Basically, stripping current is proportional to the square root of the scan rate ${ }^{11}$. The influence of scan rate on the slope of As(III) determination was studied from $40-100 \mathrm{mV} / \mathrm{s}$ (data not shown). The higher the scan rate, the more increasing in the signal but the peak become broader. To meet criteria of both high sensitivity and a well-defined stripping peak, the scan rate of $90 \mathrm{mV} / \mathrm{s}$ was chosen for subsequent experiments.

\section{Deposition time}

The effect of deposition time on the sensitivity of As(III) determination considered from a slope of calibration curve from the concentrations of 5,10 , 15 , and $20 \mu \mathrm{g} / 1 \mathrm{As}(\mathrm{III})$ standard solutions was examined within a range of 120-300 s (Fig. 6). At longer deposition time, higher sensitivity was obtained as expected as greater amount of analyte
Table 1 The FI-DPASV optimum conditions for As(III) determination.

\begin{tabular}{lc}
\hline Conditions & Optimum values \\
\hline [HCl] as supporting electrolyte (M) & 0.20 \\
Deposition potential (V) & -0.30 \\
Scan rate $(\mathrm{mV} / \mathrm{s})$ & 90 \\
Flow rate $(\mathrm{ml} / \mathrm{min})$ & 2.5 \\
Deposition time (s) & 240 \\
\hline
\end{tabular}

was deposited on the gold film electrode. In the case of high As(III) concentrations, however, short deposition time was required to avoid the saturation of electrode surface. Even though longer deposition time can be applied for low concentrations of As(III), the resulting decrease of sample throughput was not suitable for routine analysis. To compromise sensitivity and analysis time, the deposition of $240 \mathrm{~s}$ was selected. The FI-DPASV optimum conditions of As(III) determination are summarized in Table 1.

\section{Reduction of As(V) to As(III)}

In general, the determination of total inorganic arsenic requires a preliminary step to reduce As(V) to As(III), followed by the determination of As(III). Then $\mathrm{As}(\mathrm{V})$ can be calculated from the difference between As(total) and As(III). To reach the maximum reduction efficiency, parameters such as the type of reducing agent, its concentration, and reduction time need to be optimized.

The peak shapes of $30 \mu \mathrm{g} / \mathrm{l}$ As(III) with and without the aforementioned reducing agents were found to be similar and appeared at the same position but, with the reducing agent, the peak current decreased (data not shown). With a peak shape and peak current suitable for further analysis, two reducing agents, KI alone and a mixture of ascorbic acid and KI, were selected.

The effect of concentrations of two reducing agents previously used in other techniques, $\mathrm{KI}$ alone and a mixture of ascorbic acid and KI, on the efficiency of the reduction of $\mathrm{As}(\mathrm{V})$ to $\mathrm{As}(\mathrm{III})$ in terms of conversion percentage with a concentration of $100 \mu \mathrm{g} / \mathrm{l} \mathrm{As}(\mathrm{V})$ is shown in Fig. 7. The percentage of conversion increased at the concentration of $\mathrm{KI}$ of up to $6.5 \mathrm{mM}$ and then decreased at higher concentrations. In the case of a mixture of ascorbic acid and KI, conversion percentage also increased up to $7.5 \mathrm{mM}$ and decreased but with much lower conversion efficiency. This is possible due to an interfering reaction from electroactive ascorbic acid. 

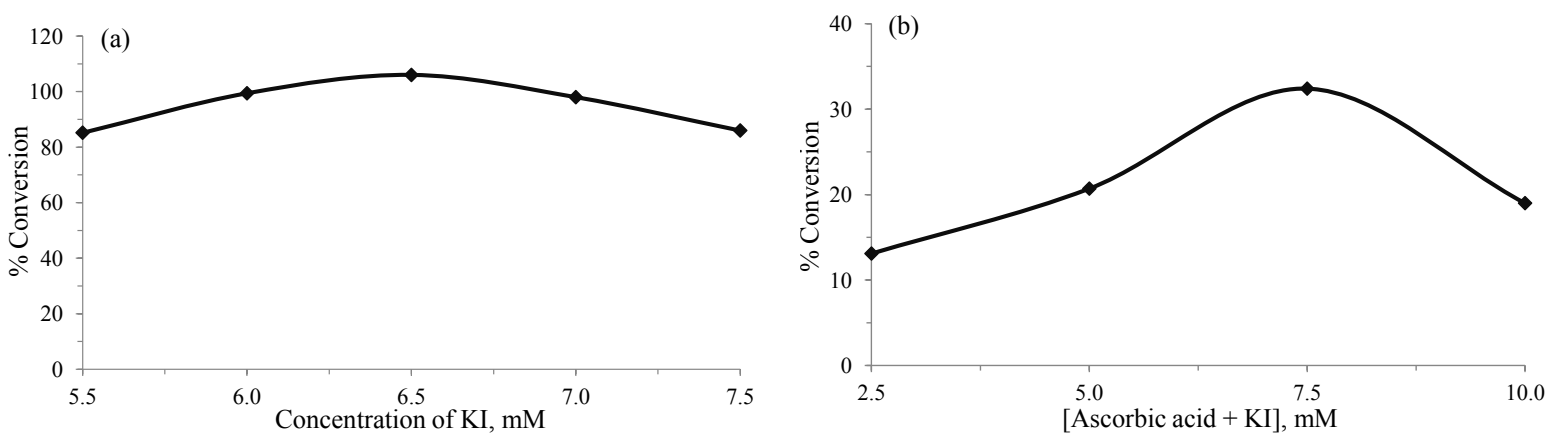

Fig. 7 Effect of concentration of (a) KI and (b) a mixture of ascorbic acid and KI as reducing agents for the reduction of $100 \mu \mathrm{g} / 1 \mathrm{As}(\mathrm{V})$; deposition potential, $-0.30 \mathrm{~V}$; deposition time, $240 \mathrm{~s}$; scan rate, $90 \mathrm{mV} / \mathrm{s}$.

Thus $6.5 \mathrm{mM}$ KI was chosen for further experiments.

To determine the time required to quantitatively reduce $\mathrm{As}(\mathrm{V})$ to $\mathrm{As}(\mathrm{III}), 100 \mu \mathrm{g} / \mathrm{l} \mathrm{As}(\mathrm{V})$ standard solution with $6.5 \mathrm{mM} \mathrm{KI}$ as reducing agent was analysed with different reduction times from 560 min (data not shown). The reduction time of 45 min was chosen as an optimum condition as it provided the highest conversion percentage.

\section{The effect of the [As(III)]:[As(V)] ratios on the conversion percentages}

The effect of [As(III)]:[As(V)] ratios to the reduction of $\mathrm{As}(\mathrm{V})$ to As(III) was tested by comparing the results obtained from the solutions with the same total arsenic concentration $(30 \mu \mathrm{g} / \mathrm{l})$ but with different ratios of $[\mathrm{As}(\mathrm{III})]:[\mathrm{As}(\mathrm{V})]$. The reduction step was carried out using $6.5 \mathrm{mM} \mathrm{KI}$ as a reducing agent with a reduction time of $45 \mathrm{~min}$. The conversion percentage of $\mathrm{As}(\mathrm{V})$ to $\mathrm{As}(\mathrm{III})$ at different ratios were in the range of $93-100 \%$ (Table 2). The reduction by using these conditions was therefore quantitative with insignificant effect from [As(III)]:[As(V)] ratios.

\section{Linear dynamic range}

The linear concentration ranges were found to be $1-$ $30 \mu \mathrm{g} / \mathrm{l}$ for As(III) and 2-100 $\mu \mathrm{g} / \mathrm{l}$ for As(total) with good correlation coefficients (Fig. 8 and Fig. 9). The different slopes of the two curves (As(III) and As(total)) are related to the presence of $6.5 \mathrm{mM}$ $\mathrm{KI}$ as reducing agent when determining As(total). The decrease in sensitivity at high concentrations of As(III) and As(V) can be caused by the electrode becoming coated with deposited As( 0 ) which is nonconductive and the gold film may become saturated.

\section{The limit of detection}

The limit of detection (LOD) was calculated from the calibration curve based on $3 S_{y / x} / m$. LOD values
Table 2 Percent conversion of As(V) to As(III) at various ratios of $[$ As(III) $]:[\mathrm{As}(\mathrm{V})]$.

\begin{tabular}{lcc}
\hline Ratios & Current $(\mu \mathrm{A})^{\mathrm{a}}$ & ${\text { Conversion }(\%)^{\mathrm{b}}}^{\mathrm{a}}$ \\
\hline $30: 0$ & $7.562 \pm 0.224$ & - \\
$5: 1$ & $7.253 \pm 0.028$ & 95.9 \\
$2: 1$ & $7.067 \pm 0.334$ & 93.5 \\
$1: 1$ & $7.066 \pm 0.164$ & 93.5 \\
$1: 2$ & $7.420 \pm 0.307$ & 98.1 \\
$1: 5$ & $7.581 \pm 0.342$ & 100.3 \\
$1: 9$ & $7.301 \pm 0.240$ & 96.6 \\
$1: 14$ & $7.582 \pm 0.177$ & 100.3 \\
$0: 30$ & $7.064 \pm 0.195$ & 93.4 \\
\hline
\end{tabular}

${ }^{\text {a }}$ Values given are the means $(n=2), \mathrm{RSD}<5 \%$.

${ }^{\mathrm{b}}$ Calculated by comparing with $7.562 \mu \mathrm{A}$, the current of As(III) with reducing agent

of 0.81 and 2.03 for AS(III) and AS(total), respectively, were obtained.

\section{Accuracy and precision}

The relative standard deviations of As(III) for 10 measurements were within $4 \%$ for 2 and $20 \mu \mathrm{g} / 1$ As(III) determination and 6\% for 10 and $100 \mu \mathrm{g} / 1$ As(total) determinations.

For inorganic arsenic speciation, no certified value of concentration has been provided for arsenic species. Hence the percentage of recovery of inorganic arsenic species was quantified by spiking As(III), As(V), and As(total) at various concentrations to natural water samples (Table 3), confirming the capabilities to apply the method for the determination of $\mathrm{As}(\mathrm{III})$ and $\mathrm{As}(\mathrm{V})$ with different ratios in natural water samples.

With Standard Reference Material (SRM) 1640 natural fresh water (NIST, USA), the result for As(total) determination of $25.18 \pm 0.74 \mu \mathrm{g} / \mathrm{l}$ was obtained which is in a good agreement with the certified value of $26.67 \pm 0.41 \mu \mathrm{g} / 1$ ( $t$-test at $95 \%)$. 


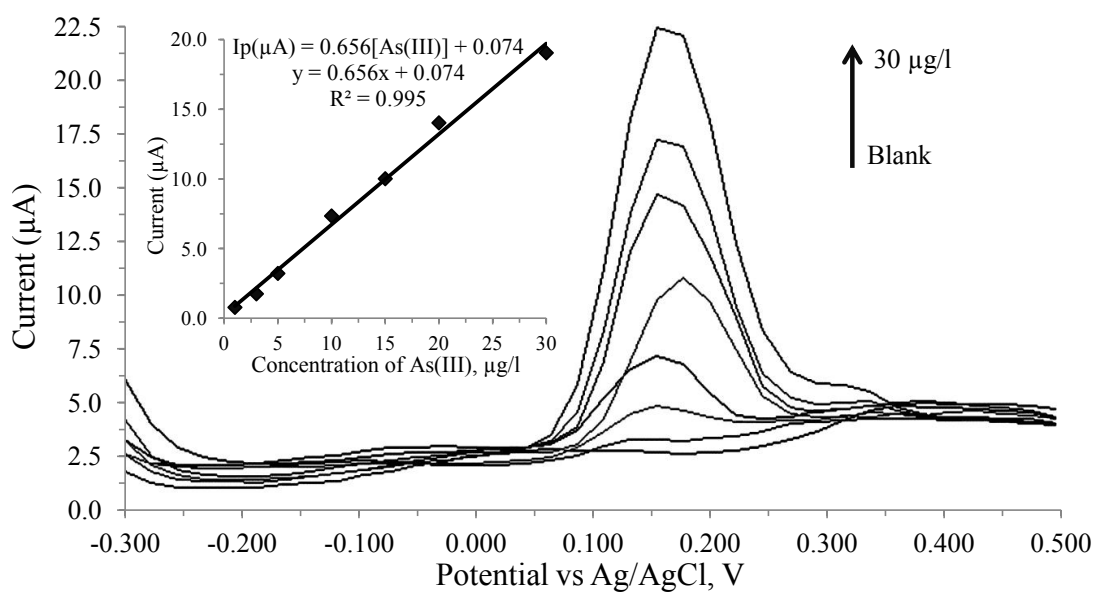

Fig. 8 Voltammograms of various concentrations of As(III) standard solutions; Blank, 1, 3, 5, 10, 15, 20, and $30 \mu \mathrm{g} / 1$ $(0.2 \mathrm{M} \mathrm{HCl})$; deposition potential, $-0.30 \mathrm{~V}$; deposition time, $240 \mathrm{~s}$; scan rate, $90 \mathrm{mV} / \mathrm{s}$.

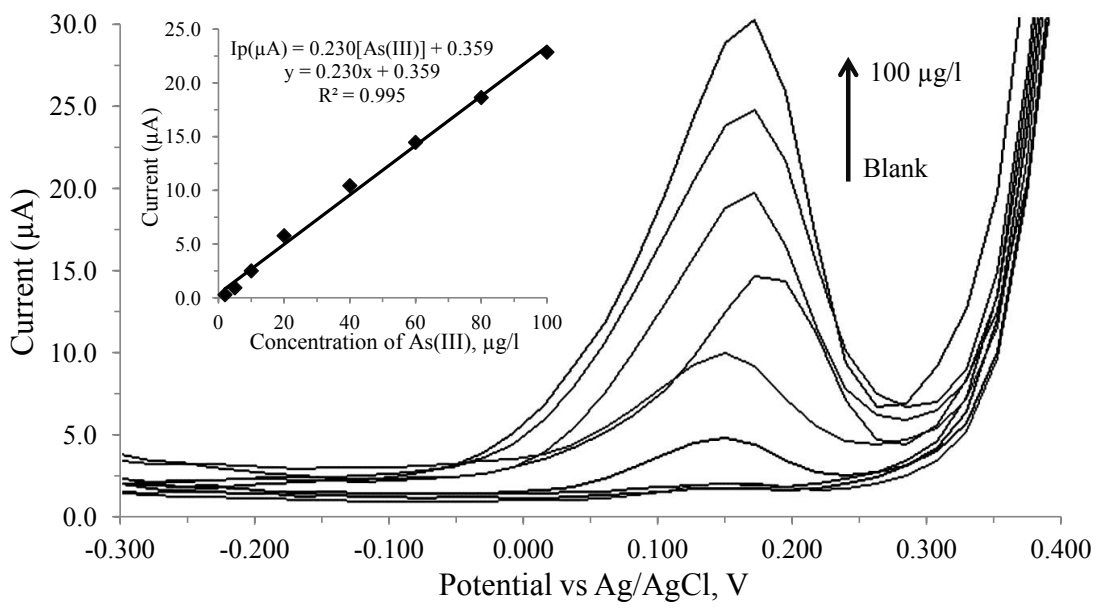

Fig. 9 Voltammograms of various concentrations of As(total) standard solutions; Blank, 2, 10, 20, 40, 60, 80, and $100 \mu \mathrm{g} / 1$ (0.2 M HCl); deposition potential, $-0.30 \mathrm{~V}$; deposition time, $240 \mathrm{~s}$; scan rate, $90 \mathrm{mV} / \mathrm{s}$.

The analytical performance represents applicability, good accuracy, and precision of the developed method (Table 4).

\section{Interference}

Possible interference for the proposed method was found to be $\mathrm{Sb}(\mathrm{III})$ for $\mathrm{As}(\mathrm{III})$ determination and $\mathrm{Hg}$ (II) followed by $\mathrm{Cu}$ (II) for As(total) determination (Table 5). Sb(III) whose chemical properties are similar to that of As(III) could interfere the As(III) determination by producing a peak at the same potential as $\mathrm{As}(\mathrm{III})$. $\mathrm{Hg}$ (II) has substantial influence on As(total) by increasing the analytical response as the stripping peak of $\mathrm{Hg}$ (II) in the presence of reducing agent appeared at the same position of As(total) peak and the degree of signal increment was dependent on the $\mathrm{Hg}$ (II) concentra- tion, with the conclusion that $\mathrm{Hg}$ (II) concentrations of $2 \mu \mathrm{g} / 1$ or more interfere with the determination of As(total). Additionally, the stripping peak of As(total) in the presence of $\mathrm{Cu}$ (II) was shifted to more positive potential and broader peak shape were obtained.

\section{Applications}

The proposed method under optimum conditions was applied to determine As(III) and As(V) in terms of As(III) and As(total) in natural water samples discharged from arsenic contaminated area in Ron Phibun Subdistrict, Ron Phibun District, Nakhon Si Thammarat Province (Table 6). As(III) and As(total) contents were calculated using calibration method and standard addition method, respectively. As $(V)$ concentrations were calculated from the dif- 
Table 3 Analytical recoveries of As(III), As(V), and As(total) added to natural water samples.

\begin{tabular}{lcccc}
\hline $\begin{array}{l}\text { Type } \\
\text { added }\end{array}$ & \multicolumn{2}{c}{ Concentration $(\mu \mathrm{g} / \mathrm{l})$} & \multirow{2}{*}{$\begin{array}{c}\text { Rec. } \\
(\%)\end{array}$} & $\begin{array}{c}\text { RSD } \\
(\%)\end{array}$ \\
\cline { 2 - 3 } & Added & Measured $^{\mathrm{a}}$ & & \\
\hline As(III) & 0.0 & $\mathrm{ND}$ & - & - \\
& 10.0 & $9.60 \pm 0.21$ & 96.0 & 2.2 \\
& 20.0 & $19.83 \pm 0.38$ & 99.1 & 1.9 \\
& 30.0 & $25.77 \pm 0.40$ & 85.9 & 1.6 \\
As(V) & 0.0 & $\mathrm{ND}$ & - & - \\
& 10.0 & $9.45 \pm 0.46$ & 94.5 & 4.9 \\
& 20.0 & $21.10 \pm 0.19$ & 105.5 & 0.9 \\
& 30.0 & $29.4 \pm 1.9$ & 98.1 & 6.6 \\
& 40.0 & $40.0 \pm 2.1$ & 100.0 & 5.4 \\
Ratios $^{\mathrm{b}}$ & 0.0 & $\mathrm{ND}$ & - & - \\
& $30.0[15: 15]$ & $28.47 \pm 0.93$ & 94.9 & 3.3 \\
& $30.0[10: 20]$ & $27.37 \pm 0.46$ & 91.2 & 1.7 \\
& $30.0[5: 25]$ & $26.96 \pm 0.67$ & 89.9 & 2.5 \\
\hline
\end{tabular}

${ }^{a}$ Values given are the means $(n=2), \mathrm{ND}=$ non-detectable $(<0.81 \mu \mathrm{g} / \mathrm{l})$.

${ }^{\mathrm{b}}$ Ratios of [As(III)]:[As(V)].

Table 4 The summary of analytical performance.

\begin{tabular}{lcc}
\hline Parameters & As(III) & As(total) \\
\hline Lin. range $^{\dagger}$ & $1.0-30$ & $2.0-100$ \\
Calib. eqn. & $y=0.656 x+0.074$ & $y=0.230 x+0.359$ \\
$R^{2}$ & 0.995 & 0.995 \\
$\mathrm{LOD}^{\dagger}$ & 0.81 & 2.03 \\
$\mathrm{RSD}$ & $4 \%$ (for $2,20 \mu \mathrm{g} / \mathrm{l})$ & $6 \%$ (for $10,100 \mu \mathrm{g} / \mathrm{l})$ \\
$\mathrm{Rec}(\%)$ & $85-105^{\mathrm{a}}$ & $88-103^{\mathrm{b}}$ \\
\hline${ }^{\dagger}(\mu \mathrm{g} / \mathrm{l})$ & \\
$\mathrm{a}$ At $10.0,20.0$, and $30.0 \mu \mathrm{g} / \mathrm{l}$. \\
$\mathrm{b}$ At 30.0 $\mu \mathrm{g} / 1$ with different ratios of As(III) and As(V).
\end{tabular}

ference in amount of As(total) and As(III). Nondetectable concentrations (ND) were in the range of to $20.5 \mu \mathrm{g} / 1$ for As(III) and $1577 \mu \mathrm{g} / \mathrm{l}$ for As(V). Most arsenic was found in $A s(V)$ form and the concentrations in certain areas exceeded the value stipulated by the WHO guideline of drinking water in $1996(10 \mu \mathrm{g} / \mathrm{l})$. To validate the method, natural water samples were spiked with As(III) and As(V) to reveal the recovery percentages in the range of $85-105 \%$ for As(III) and $85-106 \%$ for As(V). The accuracy of the method was evaluated by analysing SRM 1640 natural fresh water and the results were in good agreement with the certified values. Concentrations of As(total) in natural water samples using the proposed method were also compared with those obtained by ICP-OES and no significant difference was found at the $99 \%$ confidence level
Table 5 The interference levels of interfering ions on As(III) and As(total) determination.

\begin{tabular}{lcc}
\hline Interferences & \multicolumn{2}{c}{ Interfering levels $(\mu \mathrm{g} / \mathrm{l})$} \\
\cline { 2 - 3 } & As(III) & As(total) \\
\hline $\mathrm{Sb}(\mathrm{III})$ & 3 & 30 \\
$\mathrm{Cd}(\mathrm{II})$ & 70 & 50 \\
$\mathrm{Cu}(\mathrm{II})$ & 100 & 8 \\
$\mathrm{Fe}(\mathrm{II})$ & 40 & 40 \\
$\mathrm{~Pb}(\mathrm{II})$ & 50 & 70 \\
$\mathrm{Hg}(\mathrm{II})$ & 40 & 2 \\
$\mathrm{Ni}(\mathrm{II})$ & 100 & 60 \\
$\mathrm{Zn}(\mathrm{II})$ & 150 & 100 \\
\hline
\end{tabular}

Table 6 Concentrations of As(III), As(V) and As(total) by FI-DPASV method compared with As(total) by ICP-OES method in natural water samples.

\begin{tabular}{|c|c|c|c|c|}
\hline \multirow{3}{*}{$\begin{array}{l}\text { Sam- } \\
\text { ple }^{\dagger}\end{array}$} & \multicolumn{4}{|c|}{ Concentration $(\mu \mathrm{g} / 1)^{\mathrm{a}}$} \\
\hline & \multicolumn{3}{|c|}{ FI-DPASV } & \multirow{2}{*}{$\frac{\text { ICP-OES }}{\text { As(total) }}$} \\
\hline & As (III) $)^{b}$ & $\mathrm{As}(\mathrm{V})^{\mathrm{c}}$ & As (total) ${ }^{\mathrm{c}}$ & \\
\hline $1 / 1$ & ND & ND & ND & ND \\
\hline $1 / 2$ & $7.75 \pm 0.11$ & $16.8 \pm 1.3$ & $24.5 \pm 1.4$ & ND \\
\hline $1 / 3$ & ND & $11.9 \pm 0.3$ & $11.9 \pm 0.3$ & ND \\
\hline $1 / 4$ & $20.5 \pm 0.1$ & $11.9 \pm 0.3$ & $32.5 \pm 0.3$ & $34 \pm 4$ \\
\hline $2 / 1$ & $2.53 \pm 0.16$ & $118 \pm 7$ & $120 \pm 7$ & $120 \pm 1$ \\
\hline $2 / 2$ & ND & $33.3 \pm 0.3$ & $33.7 \pm 0.3$ & ND \\
\hline $2 / 3$ & $1.12 \pm 0.07$ & $230 \pm 4$ & $231 \pm 4$ & $231 \pm 1$ \\
\hline $2 / 4$ & $1.46 \pm 0.02$ & $173 \pm 3$ & $175 \pm 3$ & $166 \pm 2$ \\
\hline $12 / 1$ & $9.06 \pm 0.14$ & $311 \pm 2$ & $320 \pm 2$ & $313 \pm 3$ \\
\hline $12 / 2$ & $2.14 \pm 0.03$ & $359 \pm 19$ & $361 \pm 19$ & $465 \pm 3$ \\
\hline $12 / 3$ & ND & ND & ND & ND \\
\hline $12 / 4$ & ND & $180 \pm 4$ & $181 \pm 4$ & $173 \pm 2$ \\
\hline $13 / 1$ & $4.19 \pm 0.02$ & $14.4 \pm 1.1$ & $18.6 \pm 1.1$ & ND \\
\hline $13 / 2$ & ND & $1577 \pm 33$ & $1577 \pm 33$ & $1587 \pm 7$ \\
\hline $13 / 3$ & ND & $9.0 \pm 0.3$ & $9.0 \pm 0.3$ & ND \\
\hline $13 / 4$ & ND & $387 \pm 7$ & $387 \pm 7$ & $404 \pm 8$ \\
\hline
\end{tabular}

${ }^{\dagger}$ Site number/sample number.

${ }^{\text {a }}$ Values given are the means $(n=2), \mathrm{RSD}<8 \%$.

b,c,d ND = non-detectable: $<0.81 \mu \mathrm{g} / 1,<2.03 \mu \mathrm{g} / \mathrm{l}$, and $<30.0 \mu \mathrm{g} / \mathrm{l}$, respectively.

( $t$-test). The method has the advantages of semiautomation, less amount of reagent consumption, short analysis time, and suitability for routine analysis.

Acknowledgements: The authors are grateful to the Centre for Innovation in Chemistry: Postgraduate Education and Research Programme in Chemistry (PERCH-CIC), Commission on Higher Education, Ministry of Education for the scholarship and research support. Finally, we also thank the Department of Chemistry, Faculty of Science 
and the Graduate School, Prince of Songkla University for partial support.

\section{REFERENCES}

1. Li X, Jia J, Wang Z (2006) Speciation of inorganic arsenic by electrochemical hydride generation atomic absorption spectrometry. Anal Chim Acta 560, 153-8.

2. Chen M, Huo Y, Wang J (2009) Speciation of inorganic arsenic in a sequential injection dual minicolumn system coupled with hydride generation atomic fluorescence spectrometry. Talanta 78, 88-93.

3. Liang P, Liu R (2007) Speciation analysis of inorganic arsenic in water samples by immobilized nanometer titanium dioxide separation and graphite furnace atomic absorption spectrometric determination. Anal Chim Acta 602, 32-6.

4. Samanta G, Chowdhury UK, Mandal BK, Chakraborti D, Sekaran NC, Tokunaga H, Ando M (2000) High performance liquid chromatography inductively coupled plasma mass spectrometry for speciation of arsenic compounds in urine. Microchem $J$ 65, 113-27.

5. Ünal Ü, Somer G (2011) A new and simple procedure for the polarographic speciation and determination of trace inorganic As(III) and As(V) species. Turk $J$ Chem 35, 779-92.

6. Jia Z, Simm AO, Dai X, Compton RG (2006) The electrochemical reaction mechanism of arsenic deposition on an Au(1 111 ) electrode. J Electroanal Chem 587, 247-53.

7. Muñoz E, Palmero S (2005) Analysis and speciation of arsenic by stripping potentiometry: a review. Talanta 65, 613-20.

8. Paul SC, Rahman MA, Siddique NEA, Alam AMS (2008) Voltammetric study of arsenic (III) and arsenic (V) in ground water of Hajigonj and Kalkini in Bangladesh. Pakistan J Anal Environ Chem 9, 49-55.

9. Luong JHT, Majid E, Male KB (2007) Analytical tools for monitoring arsenic in the environment. Open Anal Chem J 1, 7-14.

10. Forsberg G, O'Laughlin JW, Megargle RG, Koirtyihann SR (1975) Determination of arsenic by anodic stripping voltammetry and differential pulse anodic stripping voltammetry. Anal Chem 47, 1586-92.

11. Sun YC, Mierzwa J, Yang MH (1997) New method of gold-film electrode preparation for anodic stripping voltammetric determination of arsenic (III and V) in seawater. Talanta 44, 1379-87.

12. Punrat E, Chuanuwatanakul S, Chailapakul O, Takayanagi T, Kaneta T, Motomizu S (2012) Determination of arsenic (III) by sequential injection/anodic stripping voltammetry (SI/ASV) using in-situ thin film-modified screen-printed carbon electrode (SPCE). J Flow Inject Anal 29, 11-6.

13. Hung DQ, Nekrassova O, Compton RG (2004) Analytical methods for inorganic arsenic in water. Talanta 64, 269-77.
14. He Y, Zheng Y, Ramnaraine M, Locke DC (2004) Differential pulse cathodic stripping voltammetric speciation of trace level inorganic arsenic compounds in natural water samples. Anal Chim Acta 511, 55-61.

15. Williams M, Fordyce F, Paijitprapapon A, Charoenchaisri P (1996) Arsenic contamination in surface drainage and groundwater in part of the southeast Asian tin belt, Nakhon Si Thammarat Province, Southern Thailand. Environ Geol 27, 16-33.

16. Greulach U, Henze G (1995) Analysis of arsenic (V) by cathodic stripping voltammetry. Anal Chim Acta 306, 217-23.

17. Na Chiangmai N (1990) Arsenic concentration in water, vegetables, fruits and hair of Amphoe Ron Phibun, Nakhon Si Thammarat Province. Songklanakarin J Sci Tech 13, 59-67. 